\title{
Abundance and microdistribution of freshwater gastropods in three streams of Moorea, French Polynesia
}

\author{
H.-T. Tina Liu ${ }^{1}$ \\ V.H. Resh ${ }^{1,2}$
}

Keywords : snails, benthos, molluscs, Clithon, Melanoides, Neritina, Septaria, Thiara, Oceania, salinity.

The microdistribution and abundance of freshwater gastropods were studied in lower reaches of three streams on Moorea, French Polynesia, during austral spring (AS) and austral fall (AF) 1994-1996. Seven species were examined: Neritina canalis Lamarck, Neritina turrita Gmelin, Clithon spinosa Budgin, Septaria porcellana Linnaeus, Neritina auriculata Lamarck, Melanoides tuberculata Müller, and Thiara granifera Lamarck; the first five species are in the Neritidae, the latter two in the Thiaridae. Most gastropod species had higher densities during AF 1996 than AS 1995 ( $p=0.0001)$ with higher densities being found in riffle than in pool habitats $(p=0.0001)$. No relationship between substrate type and either species presence-abundance or shell size was observed. A stepwise multiple regression indicated that velocity, depth, and substrate roughness were determinants of gastropod abundance for some species within these streams. A distinct microhabitat preference for the bottoms of rocks was observed for $C$. spinosa and $N$. canalis. The limited range of $N$. auriculata's occurrence within streams results from its salinity tolerance and response to hydraulic stress.

Microdistribution et abondance de gastéropodes d'eau douce dans trois rivières de Moorea, Polynésie française

Mots clés : Gastéropode, benthos, mollusques, Clithon, Melanoides, Neritina, Septaria, Océanie, salinité.

La microdistribution et l'abondance de gastéropodes d'eau douce ont été étudiées dans les cours inférieurs de trois rivières de Moorea, Polynésie française, pendant le printemps austral (AS) et l'automne austral (AF) 1994-1996. Sept espèces ont été étudiées : Neritina canalis Lamarck, Neritina turrita Gmelin, Clithon spinosa Budgin, Septaria porcellana Linnaeus, Neritina auriculata Lamarck, Melanoides tuberculata Müller et Thiara granifera Lamarck. Les cinq premières sont des Neritidae, les deux autrés des Thiaridae. La plupart des espèces avaient des densités plus élevées pendant l'AF 1996 que l'AS $1995(\mathrm{p}=0.0001)$ et de plus fortes densités dans les habitats de seuils que de mouilles $(p=0.0001)$. Aucune relation n'a été observée entre le type de substrat et l'abondance ou la taille des coquilles. Une régression multiple a indiqué que le courant, la profondeur et la rugosité du substrat étaient les facteurs déterminants de l'abondance de certaines espèces de gastéropodes dans ces rivières. Une préférence marquée pour les fonds rocheux a été observée chez $C$. spinosa et $N$. canalis. La répartition limitée de $N$ auriculata dans ces rivières résulte de sa tolérance à la salinité et de sa réponse au stress hydraulique.

\section{Introduction}

The Neritidae and Thiaridae are the two most abundant gastropod families found in streams and rivers of Pacific islands (Haynes 1988). These snails comprise a major portion of the stream macroinvertebrate fauna in Oceania (Resh \& de Szalay 1995). Neritid snails have

\footnotetext{
1. Department of Environmental Science, Policy \& Management, University of California, Berkeley, California 94720, U.S.A. 2. Address reprint requests to Dr. Vincent H. Resh, Division of Insect Biology, University of California, Berkeley, 201 Wellman Hall, Berkeley, California 94720-3112.
}

a diadromous life cycle ; they are confined to freshwater as adults but they complete their larval development in marine environments (Resh et al. 1992). These gastropods first enter freshwater habitats as small snails from the sea and migrate upstream until they have reached adult sizes ; after this, they reproduce and their veliger larvae migrate downstream into the marine environment where metamorphosis into small snails occurs. Stream-inhabiting thiarid snails do not exhibit this migration to ocean habitats and they reproduce in freshwaters (sometimes parthenogenetically) (Resh et al. 1990, 1992).

Freshwater-inhabiting neritid snails, along with most other stream-dwelling fishes and crustaceans, are 
descendants of marine forms that have colonized stream habitats on tropical islands (Ford \& Kinzie 1982). The freshwater species in the Neritidae evolved from the marine genus Nerita (Govidan \& Natarajan 1972). Previous studies suggest that adaptation of neritid snails to freshwater environments has occurred several times, indicating that each freshwater genus of the Neritidae represents a separate line of evolution (Haynes 1988 and references cited therein).

Habitat selection has been described for some intertidal neritids (Bovbjerg 1984) and other freshwater gastropods, such as the Mediterranean land snail Theba pisana Müller (Hazel \& Johnson 1990). However, microhabitat preferences, as well as environmental features that influence the abundance and microdistribution of freshwater gastropod populations on Pacific islands are not well known.

The objectives of this study are (1) to examine seasonal and spatial differences in densities of the different freshwater gastropod species that occur in three streams on a small Pacific island ; and (2) to examine factors influencing density and microdistribution of freshwater snails in these habitats. In this study, field and laboratory experiments examine the influence of substrate composition and roughness, velocity, depth, and salinity on the population densities and microdistribution of seven species of snails occurring on Moorea.

\section{Methods}

\subsection{Site description}

Field data were collected from the lower reaches of three streams on the island of Moorea, French Polynesia ; field and laboratory studies were conducted during October and November 1995 (austral spring, AS) and May and June 1996 (austral fall, AF). In this study, lower reaches are defined as stream sites located within $1 \mathrm{~km}$ of the ocean. Size distribution data on gastropods in the Uufau river were collected during May and November 1994. Climate and other physical aspects influence stream discharge on Moorea, which has two seasons : hot and rainy (November to April), and cool and dry (May to October).

The first study site begins $400 \mathrm{~m}$ upstream from the Opunohu Bay at the first road bridge located in the Opunohu Valley (site MPIV in Resh et al. 1990). The canopy is dominated by Tahitian chestnut [Legumenoceae, Inocarpus fagiferus (Parkinson) Fosberg] and hibiscus [Malvaceae, Hibiscus tiliaceus L.] ; taro [Araceae, Colocasia esculenta (Schott)] plants surround the stream bed. The second study site, in the Uufau river near Haapiti on the western side of Moorea, begins
$75 \mathrm{~m}$ upstream from the mouth of the river at the circum-island road bridge. The canopy there is dominated by hibiscus. The fauna in parts of the Uufau river site are subjected to regular, tidal seawater-inundation. The third study site was located in the Afareaitu river on the eastern side of Moorea, downstream from the circum-island road bridge, approximately $600 \mathrm{~m}$ upstream from Afareaitu Bay. The canopy there is dominated by hibiscus.

Sites studied in these three streams measured $\leq 150$ $m$ in total length. Study sites were selected for their high gastropod species-richness based on previous studies of streams on Moorea (Resh et al. 1990). All sites are third-order streams.

\subsection{Species examined}

The gastropod assemblage in the three streams examined consisted of seven species : Neritina canalis Lamarck, Neritina turrita Gmelin, Clithon spinosa Budgin, Septaria porcellana Linnaeus, Neritina auriculata Lamarck, Melanoides tuberculata Müller, and Thiara granifera Lamarck ; the first five species are in the family Neritidae, the latter two in the Thiaridae. Two additional neritids have been reported from Moorea : Neritilia rubida Pease and Neritina dilatata Broderip (Marquet 1987,1988 and Pointier \& Marquet 1990) but these were not collected in this study.

All seven species occurred in all three streams. However, species differences in longitudinal distributional patterns within these streams were observed in this and previous studies. $N$. canalis, which can be identified by its pale orange operculum with black stripes and a red-brown border (Haynes 1984), has been found at elevations ranging from $0-400 \mathrm{~m}$ on Moorea and nearby Tahiti (Marquet 1987,1988). N. turrita, with a thin and shiny shell and an operculum that is creamorange with a black nucleus (Haynes 1984), is the most motile species under laboratory observations (Resh et at. 1990) but it is most frequently found at lower elevations, ranging from 0-5 m (Marquet 1987, 1988). $C$. spinosa, characterized by its long and thin spines projecting backwards, has been found in elevations ranging from 0-10 m (Marquet 1987,1988). S. porcellana, easily distinguished because of its limpet-like form (Haynes 1988), is the least motile species under laboratory observations (Resh et al. 1990) but it has been found at over $100 \mathrm{~m}$ elevations (Resh et al. 1990). In contrast, N. auriculata, with a columella area extended sideways into wings (Haynes 1984), has only been found in the lower reaches of the stream, often where saltwater tidally intrudes into freshwater habitats. $T$. granifera can be distinguished by their longer shells and granulated exterior. M. tuberculata can be distin- 
guished by their smooth shell and spiral lines. On Moorea and Tahiti, $T$. granifera occurs at elevations ranging from 0-10 $\mathrm{m}$ (Marquet 1987, 1988) and M. tuberculata, the most common freshwater snail in French Polynesia (Pointier \& Marquet 1990), has been found in elevations ranging from $0-800 \mathrm{~m}$ (Marquet 1987, 1988).

\subsection{Field sampling methods}

Field observations consisted of sampling for substrate preference, and determination of population densities and shell-size range of each gastropod species within each stream. Two different habitats were examined : riffles and pools. Riffles are fast-flowing waters, usually shallow in depth and with turbulent flow. Pools are slow-moving waters, deeper, and with less turbulent flow. Seven to nine pairs of riffles and pools were chosen for study at the lower-reach sites of each of the streams examined.

\subsubsection{Density counts, substrate composition and asso- ciated measurements}

Densities of the different gastropod species was determined from Surber sampler collections (Merritt et al. 1996). Ten samples were collected within each of the riffle and pool habitats studied in each stream during both AS $1995\left(0.1 \mathrm{~m}^{2}\right.$ sample area ; 70 samples total) and AF $1996\left(0.1 \mathrm{~m}^{2}\right.$ quadrat area ; 90 samples total). Within each quadrat, all large stones were overturned, surfaces' scraped, and substrate bottom agitated and examined. Snails collected were identified and counted.

Measurements of average water depth and velocity were taken at each Surber-sampler area. Three velocity measurements were made (and averaged) by releasing a neutrally buoyant glass vial at the surface of the water and noting the time it took to travel a distance of $1 \mathrm{~m}$. Substrate roughness was measured during both AS and AF, using the method of Winget (1985). To do this, visual estimates of percent substrate composition was conducted in each quadrat $\left(0.1 \mathrm{~m}^{2}\right.$ quadrat area, for both $\mathrm{AS}$ and $\mathrm{AF})$. Roughness (Kv) was calculated as : $\mathrm{Kv}=\left(5 \mathrm{C}_{1}+3 \mathrm{C}_{2}+\mathrm{C}_{3}\right) / 9$, with $\mathrm{C}_{1}=$ most dominant substrate type, $\mathrm{C}_{2}=$ second most dominant substratum type, and $\mathrm{C}_{3}=$ third most dominant substratum type ; scores for substrate type are boulders $=4$, large cobbles $=3$, small cobbles $=2$, and granules $=1$ (Statzner et al. 1988). Substratum size classes were modified from those given in Winget (1985) and Statzner et al. (1988) as follows : boulders $=>256 \mathrm{~mm}$ (intermediate axis length) ; large cobbles $=128-256 \mathrm{~mm}$; small cobbles $=64-127 \mathrm{~mm}$; and granules $=<64 \mathrm{~mm}$. As an example, if we found $50 \%$ granules, $40 \%$ small cobbles and $10 \%$ boulders within one quadrat, the equation would be : $\mathrm{K}_{\mathrm{v}}=\left(5(1)+3(2)+1(4) / 9\right.$ and $\mathrm{K}_{\mathrm{v}}$ $=1.67$. Measurements of depth, velocity, and substrate roughness were used in the multiple regression analysis to determine the variables affecting the abundance of gastropods within these streams.

\subsubsection{Abundance and substrate size}

Pebble counts were conducted along each of three transects across the width of each stream during the months of May and June 1996 (AF) to examine whether snails showed a preference for certain substrate sizes. By touching the stream bottom at set intervals, 17 substrate particles were sampled along each transect. An aquarium net was placed below each substrate particle to catch snails that dropped off. Classification of substrate type, based on the length of the intermediate axis of each particle, was done as above. The width of each transect was used to evenly space the pebble counts (e.g. width $=3 \mathrm{~m}$, interval length along the transect $=0.18 \mathrm{~m}$ ), and the length of the habitat was used to evenly space between the transects (e.g. length of habitat $=10 \mathrm{~m}$, length between each transect $=$ $3.3 \mathrm{~m}$ ). For 'each substrate particle sampled; all attached snails were identified, counted, and shell size of each species was measured (as the longest anteriorposterior dimension of the shell) using calipers.

\subsubsection{Size distribution}

In addition to size measurements made in pebblecount collections, a small-scale longitudinal study spanning $66 \mathrm{~m}$ of the lower reach of the Uufau river was conducted to examine the size distribution of $N$. auriculata in terms of distance from the ocean (i.e. the river mouth). Three sites, 0-6 m (mostly freshwater), 36-42 m, and 60-66 m (mostly seawater) distance, respectively, from the first upstream riffle habitat from the ocean were selected. Rocks were randomly chosen within each site and the longest axis of the shell of $N$. auriculata was measured.

\subsection{Laboratory methods}

\subsubsection{Microhabitat preference}

Groups of 10-17 C. spinosa and N. canalis, collected from the Opunohu river field site, were placed in freshwater aquaria that contained cobble-sized stream rocks. The location of each snail in the aquaria was recorded in the morning (between 0700-0900) and in evening (between 1700-1900) over three days. Snails were recorded as occupying one of six different habitats : the top of the aquaria ; side of aquaria ; bottom of aquaria ; top of the rock, within an aquarium ; bottom of rock; and side of rock. Other activity patterns were also noted during these observations. Six replicate 
groups of $C$. spinosa and $N$. canalis were observed in the laboratory.

\subsubsection{Response to hydraulic stress}

Using a garden hose set at five fixed discharges of freshwater, the ability of five species of neritid snails to maintain their hold on the substrate was tested. Individual snails were placed on a flat concrete substrate, acclimated for two minutes, and then subjected to the full discharge directed at them, horizontal to the substrate, for 10 seconds. At least six individuals of each species were tested at five discharge levels : $2.31 / \mathrm{min} ; 3.4$ $1 / \mathrm{min} ; 5.7 \mathrm{l} / \mathrm{min} ; 7.2 \mathrm{1} / \mathrm{min}$; and $8.1 \mathrm{1} / \mathrm{min}$.

\subsubsection{Salinity bioassay}

To determine how salinity influences the distribution and abundance of $N$. auriculata, snails were collected from different sites in the Uufau river. Approximately $50 \mathrm{~N}$. auriculata were collected in freshwater habitats $110 \mathrm{~m}$ from the mouth of the river. One-half of the collected group was kept in flow-through freshwater aquaria ; the other half was placed in flow-through seawater aquaria. Snails were allowed to acclimate in both habitats for 24 hours before observations were made. Percent survival was recorded on a daily basis, along with air and water temperatures. This experiment was replicated twice. The same procedure was conducted with downstream collected $N$. auriculata (40 $\mathrm{m}$ from the river mouth, an area with seawater intrusion), and replicated three times.

We also examined the short-term ( $\leq 154$ hours) survivorship of $N$. auriculata and four other species of freshwater-inhabiting Neritidae ( $N$. canalis, $N$. turrita, C. spinosa, S. porcellana) and marine-inhabiting neritids (Nerita spp.) in seawater and freshwater rearings. Daily observations of survivorship were recorded.

\subsection{Data analysis}

After transforming $\left(\log _{10}(\mathrm{X}+1)\right)$ density counts, a three-way ANOVA was conducted to determine how season, location, and habitat affect densities of gastropods within these streams. After an arc sine transformation, a two-way ANOVA, followed by a Tukey's test; was used to test differences in microhabitat usage between day and night. A stepwise multiple regression analysis was conducted to determine the influence of velocity, depth, and substrate roughness on snail abundance.

\section{Results}

\subsection{Densities}

Total gastropod densities (i.e. three streams combined) in riffles $\left(90.0 \pm 11.9\right.$ individuals $\left./ \mathrm{m}^{2}\right)$ and pools
$(44.8 \pm 5.5$ individuals $/ \mathrm{m} 2)$ were statistically different $(p=0.0001)$. Seasonal differences in total gastropod densities were statistically significant with higher densities found during $\mathrm{AF}$ ( $\mathrm{AF}=95.8 \pm 11.0$ individuals $/ \mathrm{m}^{2}, \mathrm{AS}=30.9 \pm 5.4$ individuals $/ \mathrm{m}^{2} ; \mathrm{p}=0.0001$ ). There were also significant differences in total densities (i.e. riffles and pools combined) between the Opunohu and Uufau $\left(70.7 \pm 6.4\right.$ and $43.1 \pm 11.1$ individuals $/ \mathrm{m}^{2}$, respectively; $p=0.0001$ ) and between the Uufau and Afareaitu $\left(43.1 \pm 11.1\right.$ and $87.9 \pm 10.5$ individuals $/ \mathrm{m}^{2}$, respectively $; p=0.0001)$. Riffle densities were significantly higher than pool densities in both the Opunohu and Afareaitu (riffles $=83.5 \pm 6.6$, pools $=57.8 \pm 6.0$ and riffles $=136.8 \pm 12.6$, pools $=39.0 \pm 3.9$, respectively, $\mathrm{p}=0.0024$ ), but no difference was observed between riffle and pool densities in the Uufau.

Densities of $N$. canalis, $C$. spinosa, and $T$. granifera were significantly higher during AF than AS (Table 1) ( $p<0.0001$ ). Densities of $N$. canalis were significantly higher in riffle than in pool habitats $(\mathrm{p}<0.0001)$ (Table 1).

\subsection{Factors influencing microdistribution}

Results from a stepwise multiple regression analysis suggest that certain physical factors influence snail abundance. An alpha of $\leq 0.05$ was used to determine which factors predicted abundance of gastropods in these three streams. In AS, significant, positive relationships were found between : substratum roughness and abundance of $N$. canalis $(\mathrm{p}=0.05)$; substratum roughness and abundance of $S$. porcellana $(\mathrm{p}=0.01)$; velocity and abundance of $M$. tuberculata $(\mathrm{p}<0.001)$, and both velocity and abundance and depth and abundance of $T$. granifera $(\mathrm{p}=0.001)$. $N$. auriculata was not included in this analysis because of its occurrence in only the Uufau.

In AF, significant, positive relationships were found between velocity and abundance of $N$. canalis $(\mathrm{p}=$ 0.0001 ), and substratum roughness and abundance of $S$. porcellana $(\mathrm{p}=0.0002)$.

\subsubsection{Size distribution}

Size distribution of $N$. auriculata increased as distance from the ocean increased, even at the small distance $(66 \mathrm{~m})$ between the extremes of the three sites examined in the Uufau. During AF 1994, the median $N$. auriculata shell size was $6 \mathrm{~mm}$ at $60-66 \mathrm{~m}$ from the first riffle, $7 \mathrm{~mm}$ at $36-42 \mathrm{~m}$ distance, and $14 \mathrm{~mm}$ at 0-6 m distance. During AS 1994, the median shell size was $5 \mathrm{~mm}$ at $60-66 \mathrm{~m}$ distance, $8 \mathrm{~mm}$ at $36-42 \mathrm{~m}$ distance, and $12 \mathrm{~mm}$ at 0-6 $\mathrm{m}$ distance. High tide salinity measurements at $60-66 \mathrm{~m}, 36-42 \mathrm{~m}$, and 0-6 m distance were $24.1 \mathrm{ppt}, 1.4 \mathrm{ppt}$ and $0 \mathrm{ppt}$, respectively. 
Table 1. Densities of snails (number of individuals $/ \mathrm{m}^{2} \pm \mathrm{SD}$ ) within each stream during AS 1995 and AF 1996.

Tableau 1. Densités de gastéropodes (nombre d'individus $/ \mathrm{m}^{2} \pm \mathrm{SD}$ ) dans chaque rivière pendant le printemps austral 1995 et l'automne austral 1996.

\begin{tabular}{|c|c|c|c|c|c|c|c|}
\hline & & \multicolumn{2}{|c|}{ Opunohu } & \multicolumn{2}{|c|}{ Uufau } & \multicolumn{2}{|c|}{ Afareaitu } \\
\hline & & Riffles & Pools & Riffles & Pools & Riffles & Pools \\
\hline & & \multicolumn{2}{|c|}{$\left(\right.$ No. $\left./ \mathrm{m}^{2} \pm \mathrm{SD}\right)$} & \multicolumn{2}{|c|}{$\left(\mathrm{No} . / \mathrm{m}^{2} \pm \mathrm{SD}\right)$} & \multicolumn{2}{|c|}{ (No. $\left./ \mathrm{m}^{2} \pm \mathrm{SD}\right)$} \\
\hline N. canalis & $\begin{array}{l}\mathrm{AS} \\
\mathrm{AF}\end{array}$ & $\begin{array}{l}18.7 \pm 1.7 \\
48.0 \pm 4.8\end{array}$ & $\begin{array}{r}2.0 \pm 0.4 \\
23.0 \pm 2.6\end{array}$ & $\begin{array}{c}0 \\
18.0 \pm \quad 3.9\end{array}$ & $\begin{array}{c}0 \\
8.0 \pm 5.9\end{array}$ & $\begin{array}{r}68.4 \pm 10.5 \\
146.7 \pm 10.6\end{array}$ & $\begin{array}{l}17.0 \pm 2.3 \\
34.0 \pm 2.9\end{array}$ \\
\hline N. turrita & $\begin{array}{l}\text { AS } \\
\text { AF }\end{array}$ & $\begin{array}{l}0.3 \\
0\end{array}$ & $\begin{array}{l}0 \\
0.7\end{array}$ & $\begin{array}{l}0 \\
0\end{array}$ & $\begin{array}{l}0 \\
0\end{array}$ & $\begin{array}{l}0 \\
0\end{array}$ & $\begin{array}{l}0 \\
0\end{array}$ \\
\hline C. spinosa & $\begin{array}{l}\text { AS } \\
\text { AF }\end{array}$ & $\begin{array}{l}8.0 \pm 0.6 \\
7.0 \pm 1.2\end{array}$ & $\begin{array}{l}3.7 \pm 1.1 \\
9.7 \pm 1.2\end{array}$ & $\begin{array}{c}3.5 \pm 1.0 \\
57.0 \pm 17.3\end{array}$ & $\begin{array}{r}2.0 \pm 0.6 \\
44.3 \pm 7.5\end{array}$ & $\begin{array}{l}10.0 \pm 2.1 \\
26.7 \pm 3.0\end{array}$ & $\begin{array}{l}10.5 \pm 1.2 \\
11.7 \pm 1.6\end{array}$ \\
\hline C. porcellana & $\begin{array}{l}\mathrm{AS} \\
\mathrm{AF}\end{array}$ & $\begin{array}{l}6.0 \pm 0.8 \\
3.7 \pm 0.7\end{array}$ & $\begin{array}{r}4.3 \pm 2.5 \\
11.0 \pm 2.5\end{array}$ & $\begin{array}{l}0.5 \\
0.3\end{array}$ & $\begin{array}{ll}5.5 \pm & 1.2 \\
0.7 \pm & 0\end{array}$ & $\begin{array}{l}1.5 \pm 0.7 \\
1.0 \pm 0\end{array}$ & $\begin{array}{l}0 \\
0\end{array}$ \\
\hline M. tuberculata & $\begin{array}{l}\mathrm{AS} \\
\mathrm{AF}\end{array}$ & $\begin{array}{l}8.0 \pm 1.7 \\
2.0 \pm 1.0\end{array}$ & $\begin{array}{l}3.7 \pm 1.7 \\
1.0 \pm 0.7\end{array}$ & $\begin{array}{c}0 \\
2.0 \pm 0\end{array}$ & $\begin{array}{l}0 \\
0.3\end{array}$ & $\begin{array}{l}0 \\
0,3\end{array}$ & $\begin{array}{c}0 \\
1.0 \pm 0\end{array}$ \\
\hline T. granifera & $\begin{array}{l}\text { AS } \\
\text { AF }\end{array}$ & $\begin{array}{r}6.3 \pm 3.2 \\
59.0 \pm 5.1\end{array}$ & $\begin{array}{r}4.0 \pm 0.8 \\
52.7 \pm 5.0\end{array}$ & $\begin{array}{l}0 \\
5.0\end{array}$ & $\begin{array}{l}0 \\
0\end{array}$ & $\begin{array}{l}0 \\
0\end{array}$ & $\begin{array}{l}0 \\
0\end{array}$ \\
\hline N. auriculata & $\begin{array}{l}\text { AS } \\
\text { AF }\end{array}$ & $\begin{array}{l}0 \\
0\end{array}$ & $\begin{array}{l}0 \\
0\end{array}$ & $\begin{array}{r}248.5 \pm 21.9 \\
4.3 \pm 1.5\end{array}$ & $\begin{array}{r}69.0 \pm 12.3 \\
7.3 \pm 2.2\end{array}$ & $\begin{array}{l}0 \\
0\end{array}$ & $\begin{array}{l}0 \\
0\end{array}$ \\
\hline Total & $\begin{array}{l}\mathrm{AS} \\
\mathrm{AF}\end{array}$ & $\begin{array}{r}47.3 \pm 2.7 \\
119.7 \pm 7.4\end{array}$ & $\begin{array}{r}17.7 \pm 1.8 \\
98.0 \pm 6.0\end{array}$ & $\begin{array}{r}4.0 \pm 0.82 \\
82.3 \pm 18.2\end{array}$ & $\begin{array}{r}7.5 \pm 1.4 \\
53.3 \pm 7.4\end{array}$ & $\begin{array}{r}80.0 \pm 11.5 \\
174.7 \pm 12.0\end{array}$ & $\begin{array}{l}27.5 \pm 3.4 \\
46.7 \pm 4.0\end{array}$ \\
\hline
\end{tabular}

\subsubsection{Substrate preference}

Organism/substrate-size relationships observed in this study indicate a general increase in total numbers of gastropods as substrate size increased (Table 2). This trend reflected the increases in abundance for three numerically dominant species $(N$. canalis, $C$. spinosa, and $S$, porcellana). However, the two melanid species ( $T$. granifera and $M$. tuberculata) were restricted to smaller substrates. $N$. auriculata were not included in the analysis because of the predominance of similar-sized (small cobbles) substrate in the Uufau.

\subsection{Microhabitat of gastropods}

$C$. spinosa and $N$. canalis used different microhabitats during both day and night $(\mathrm{p}=0.0001, \mathrm{p}=0.0001$, respectively). Bottoms of rocks and aquaria were the most common surfaces used by $C$. spinosa, followed by sides of aquaria and tops of rocks. Bottoms of rocks were the most common surfaces used by $N$. canalis, followed by bottoms and sides of aquaria (Table 3). No significant differences between day and night use was observed.

\subsection{Response to hydraulic stress}

Of the five neritid species tested, $N$. auriculata was dislodged most frequently at the five discharge levels tested ; $S$. porcellana was not dislodged at any of the levels tested and $N$. canalis was dislodged at lower discharges than most other species tested (Table 4).

\subsection{Salinity bioassay}

In the replicated trials, $100 \%$ of upstream-collected (i.e. from freshwater habitat) $N$. auriculata survived 
Table 2. Substrate preference (number of individuals/number of particles of that size) of snails in three streams on Moorea during AF 1996.

Tableau 2. Préférence de substrats (nombre d'individus/nombre de particules de chaque taille) des gastéropodes dans 3 rivières de Moorea pendant l'automne austral 1996.

\begin{tabular}{|c|c|c|c|c|c|c|c|c|}
\hline & $\begin{array}{l}\text { N. canalis } \\
(\mathrm{n}=423)\end{array}$ & $\begin{array}{c}\text { C. spinosa } \\
(\mathrm{n}=470)\end{array}$ & $\begin{array}{c}\text { S. porcellana } \\
(n=51)\end{array}$ & $\begin{array}{c}\text { N. turrita } \\
(\mathrm{n}=5)\end{array}$ & $\begin{array}{c}\text { N. auriculata } \\
(\mathrm{n}=17)\end{array}$ & $\begin{array}{c}\text { T. granifera } \\
(\mathrm{n}=27)\end{array}$ & $\begin{array}{l}\text { M. tuberculata } \\
(\mathrm{n}=2)\end{array}$ & $\begin{array}{c}\text { Totals } \\
(n=995)\end{array}$ \\
\hline granules $(n=342)$ & 0.18 & 0.28 & 0.01 & 0 & 0.01 & 0.03 & 0 & 0.52 \\
\hline small cobbles $(n=377)$ & 0.50 & 0.67 & 0.05 & 0 & 0.02 & 0.04 & 0.01 & 1.29 \\
\hline large cobbles $(n=126)$ & 1.17 & 0.79 & 0.13 & 0.02 & 0.03 & 0 & 0 & 2.15 \\
\hline boulders $(n=16)$ & 1.31 & 0.69 & 0.81 & 0 & 0 & 0 & 0 & 2.81 \\
\hline
\end{tabular}

Table 3. Average time (expressed as percent of total time) C. spinosa and N. canalis spent in each microhabitat (day and night combined). Letters (a, b, c, d) indicate statistically significant differences (Tukey's Test) between microhabitat use.

Tableau 3. Durée moyenne (exprimée en \% du temps total) passée par C. spinosa et $N$. canalis dans chaque microhabitat (nuit et jour confondus). Les lettres (a, b, c, d) indiquent les différences statistiquement significatives (Test de Tukey) de l'utilisation des microhabitats.

\begin{tabular}{lcc}
\hline & Clithon spinosa & Neritina canalis \\
\hline Top of aquaria & $0^{\mathrm{b}}$ & $0^{\mathrm{c}}$ \\
Side of aquaria & $14.4^{\mathrm{b}}$ & $17.8^{\mathrm{bd}}$ \\
Bottom of aquaria & $38.0^{\mathrm{a}}$ & $26.0^{\mathrm{bc}}$ \\
Top of rock & $1.8^{\mathrm{b}}$ & $1.2^{\mathrm{b}}$ \\
Side of rock & $0.8^{\mathrm{b}}$ & $2.8^{\mathrm{b}}$ \\
Bottom of rock & $45.2^{\mathrm{a}}$ & $52.6^{\mathrm{a}}$ \\
\hline
\end{tabular}

Table 4. Percentage of neritid individuals dislodged by exposure to various discharges. An individual that remained attached for $\geq 10$ seconds is considered as not being dislodged. NT= not tested.

Tableau 4. Pourcentage d'individus de Neretidae délogées après exposition à diverses augmentations brutales de débit. Un individu qui reste fixé pendant 10 secondes ou plus est considéré non délogé. NT = non testé.

\begin{tabular}{lccccc}
\hline & $2.31 / \mathrm{min}$ & $3.41 / \mathrm{min}$ & $5.7 \mathrm{~V} / \mathrm{min}$ & $7.2 \mathrm{~V} / \mathrm{min}$ & $8.11 / \mathrm{min}$ \\
\hline N. auriculata. & 31.3 & 34.4 & 46.9 & $\mathrm{NT}$ & 100 \\
N. canalis & 0 & 1.6 & 10.4 & 50.0 & 100 \\
N. turrita & 0 & 0 & 0 & 50.0 & 100 \\
S. porcellana & 0 & 0 & 0 & 0 & 0 \\
C. spinosa & 0 & 0 & 0 & 16.7 & 100 \\
\hline
\end{tabular}

when placed in freshwater and $60.9-65 \%$ of these survived in seawater after 168 hours (Table 5). In contrast, $100 \%$ of downstream-collected (i.e. from seawater habitat) $N$. auriculata survived when placed in seawater and $69 \%$ of those survived in freshwater after 168 hours (Table 5). Results for downstreamimens collected specimens in seawater were similar for shorterterm exposures ; however, results in freshwater replicates were more variable (Table 5).
Short-term survivorship experiments conducted with $N$. turrita, S. porcellana, $N$. canalis, and $C$. spinosa indicate far lower survivorship than $N$. auriculata when these species were placed in seawater (Table 6). Survivorship of the marine snails Nerita spp. were also lower than $N$. auriculata in freshwater. 
Table 5. Survivorship (as \% of total) of upstream-and downstream-collected $N$. auriculata in freshwater and seawater rearings. NT $=$ not tested for that replicate.

Tableau 5. Survie (en \% du total) des $N$. auriculata récoltées en amont ou en aval et élevées en eau douce et en eau de mer. NT $=$ repliquat non testé.

\begin{tabular}{|c|c|c|c|c|c|}
\hline & \multicolumn{2}{|c|}{ UPSTREAM } & & \multicolumn{2}{|c|}{ DOWNSTREAM } \\
\hline & Freshwater & Seawater & & Freshwater & Seawater \\
\hline & $(n=26 / 20)$ & $(n=23 / 20)$ & & $(n=29 / 16 / 19)$ & $(n=30 / 23 / 24)$ \\
\hline $24 \mathrm{hrs}$ & $100 / 100$ & $87 / 100$ & $24 \mathrm{hrs}$ & $100 / 75 / 100$ & $100 / 100 / 100$ \\
\hline $48 \mathrm{hrs}$ & $100 / 100$ & $73.9 / 95$ & $48 \mathrm{hrs}$ & $89.7 / 75 / 88.9$ & $100 / 100 / 100$ \\
\hline $72 \mathrm{hrs}$ & $100 / 100$ & $65.2 / 80$ & $72 \mathrm{hrs}$ & $79.3 / 62.5 / 88.9$ & $100 / 100 / 100$ \\
\hline $96 \mathrm{hrs}$ & $100 / 100$ & $60.9 / 75$ & $96 \mathrm{hrs}$ & $75.9 / 43.8 / \mathrm{NT}$ & $100 / 95.7 / \mathrm{NT}$ \\
\hline $120 \mathrm{hrs}$ & $100 / 100$ & $60.9 / 65$ & 120 hrs & $75.9 / 43.8 / \mathrm{NT}$ & $100 / 95.7 / \mathrm{NT}$ \\
\hline $144 \mathrm{hrs}$ & $100 / 100$ & $60.9 / 65$ & $144 \mathrm{hrs}$ & 69/NT/NT & $100 / \mathrm{NT} / \mathrm{NT}$ \\
\hline $168 \mathrm{hrs}$ & $100 / 100$ & $60.9 / 65$ & $168 \mathrm{hrs}$ & 69/NT/NT & 100/NT/NT \\
\hline
\end{tabular}

\section{Discussion}

- Abiotic factors, such as water velocity and substrate type, are dominant factors influencing microhabitat use of freshwater gastropods (Haynes 1988). Species distributions are often the result of large-scale habitat requirements, yet species also selectively distribute themselves within streams in response to microhabitat conditions. An understanding of the relationships between individual species and the factors influencing their microdistribution may reveal the ways in which similar species can coexist within habitats.

Haynes (1988) reported general habitat preferences for some of the freshwater species examined in this study, and concluded that water velocity and type of substrate were the dominant factors affecting the distribution of gastropods upstream from tidal influences. Our results indicated that velocity, depth, and substrate roughness affected the distribution of some species of gastropods within these streams but not other species. Abiotic elements (e.g. water depth, velocity and substrate) have also been identified as affecting distribution and abundance of molluscs such as freshwater mussels (Layzer \& Madison 1995). Furthermore, biotic elements that we did not measure, such as food availability and occurrence, undoubtedly influence distribution as well. In contrast, marine Neritidae actively select microhabitats based on physical factors of light, water depth, and slope (Bovbjerg 1984).

\subsection{Patterns of microhabitat use of the species exa- mined}

Neritina canalis is found in both lower and upper reaches of the three streams examined. Haynes (1988) reported that this species occurs on the sides or on the undersides of rocks. In the present study, they occurred most commonly in faster flowing waters (riffles) and 
Table 6. Survivorship (as \% of total) of five species of freshwater-inhabiting Neritidae in seawater rearings and marine-inhabiting Nerita spp. in freshwater rearings.

Tableau 6. Survie (en \% du total) de cinq espèces de Neretidae vivant en eau douce et élevées en eau de mer et de Nerita spp. marines et élevées en eau douce.

\begin{tabular}{rcccccc}
\hline & $\begin{array}{c}\text { N. turrita } \\
(\mathrm{n}=6)\end{array}$ & $\begin{array}{c}\text { S. porcellana } \\
(\mathrm{n}=8)\end{array}$ & $\begin{array}{c}\text { N. canalis } \\
(\mathrm{n}=15)\end{array}$ & $\begin{array}{c}\text { C. spinosa } \\
(\mathrm{n}=17)\end{array}$ & $\begin{array}{c}\text { N. auriculata } \\
(\mathrm{n}=40)\end{array}$ & $\begin{array}{c}\text { Nerita } \text { spp. } \\
(\mathrm{n}=50)\end{array}$ \\
\hline $8 \mathrm{hrs}$ & 100 & 75 & 100 & 100 & 100 & 100 \\
$12 \mathrm{hrs}$ & 100 & $\mathrm{NT}$ & 100 & NT & 100 & 100 \\
$24 \mathrm{hrs}$ & 66 & 0 & 93 & 0 & 100 & 100 \\
$48 \mathrm{hrs}$ & 0 & 0 & 0 & 0 & 98 & 18 \\
$72 \mathrm{hrs}$ & 0 & 0 & 0 & 0 & 95 & 0 \\
$154 \mathrm{hrs}$ & 0 & 0 & 0 & 0 & 93 & 0 \\
\hline
\end{tabular}

on the sides or the undersides of large cobbles and boulders. Laboratory experiments indicated that during both day and night, most individuals were found attached to the bottoms of rocks (Table 3). Schneider \& Frost (1986) observed that even low velocity conditions could dislodge tropical freshwater neritid snails. Hydraulic stress test data indicate that $N$. canalis has a lower ability to withstand dislodgment by current than other neritids examined except $N$. auriculata. The refuge against a strong, downstream current, which is available underneath stones, can further explain their common occurrence on the bottoms of rocks.

Neritina turrita is confined to the lower reaches of these streams. Haynes (1985) found this species occurring in mud substrates in slower moving currents. Although this species was rarely collected, strong microhabitat preferences in the field were observed. They were commonly found attached to the tops of large cobbles and boulders in the side regions of the streams and up to $1 \mathrm{~m}$ (vertical distance) above the water surface. These side regions of streams are characterized by slower moving waters. The results from our laboratory experiments showed that most $N$. turrita snails occurred at the tops of half-filled or full aquaria during both the day and night (data not shown), often above the water line. Despite its high motility in laboratory rearings, it is restricted to lower elevation sites near the mouth of rivers on Moorea (Resh et al. 1990).

Clithon spinosa is found throughout the lower reaches of these streams. Haynes (1985) reported this species occurring on rocks in faster flowing waters. In this study, this species was found on the bottoms of rocks in riffles in most of the sites. These snails have adapted to these strong downstream currents by finding refuge on the undersides of rocks to avoid being accidentally swept downstream (although their abili- ties to resist dislodgment are relatively high). Many can be found on small and large cobbles, as well as boulders within these streams. Laboratory experiments suggest that they occur most frequently under rocks during the day and night (Table 3 ). These results correlate with our field observations (made during both seasons).

Unique behaviors were also noted for $C$. spinosa in aquaria. They were observed travelling unidirectionally, in a straight line, along the sides of the aquaria during some nights. These are likely related to upstream migrations. This single-line movement behavior has also been noted in other species of neritid snails (Schneider \& Frost 1986). Statzner et al. (1988) related this single-file behavior in neritid snails to reductions in hydraulic stress.

Septaria porcellana is found in upper and middle elevations $(<100 \mathrm{~m})$ in these streams. Haynes (1988) reported that it occurs on the upper surfaces of rocks, as well as on the sides of rocks. Resh et al. (1990) found them attached to boulders in the fastest flowing habitats in Moorea streams. We found them occurring in both riffles and pools, on the upper surfaces and sides of large cobbles and boulders. Vermeij (1971) has noted that species with a structural adaptive strategy (such as a limpet-shaped shell) permits individuals to hold on to surfaces very tightly. These snails have an adaptive advantage over other species in that this structure permits them to live in faster flowing waters. $S$. porcellana was the least motile in laboratory rearings but it had the highest ability to resist dislodgment, even in high flows.

Melanoides tuberculata and Thiara granifera were most common where fine particles made up the streambed substrate. A few were found attached to the sides of small cobbles as well. They are found in both 
fast and slower moving waters. In contrast, Dudgeon (1989) found this species occurring most frequently in slower moving or standing waters. The hydraulic stress test was not conducted on these two species because their smaller shell size made it difficult to test its attachment ability.

Neritina auriculata was sampled only at the Uufau river and there it was most abundant in the downstream-most riffle and pool habitats. This species also occurs in the lowest reaches of the other streams where seawater influences freshwater habitats. They were found attached to all available substrate types. High numbers of $N$. auriculata occur where few other freshwater species were found, as also observed by Resh et al. (1990).

Freshwater animals and plants, including neritid snails, vary in their ability to tolerate salinity (Ford \& Kinzie 1982). The occurrence and abundance of $N$. auriculata in high salinity habitats, in areas where other freshwater gastropod species do not generally occur is a result of this. Under high tide conditions, salinity levels start to decrease at the end of the first riffle in the Uufau river, a boundary that also defines the uppermost limit of $N$. auriculata's distribution and the area where typical freshwater species begin to occur.

The survivorship of upstream collected $N$ : auriculata (e.g. in habitats with low salinity levels and low ionic content) suggest that once $N$. auriculata migrate out of seawater influence, their tolerance to salinity decreases. Lower survivorship in freshwater habitats was also observed for $N$. auriculata collected from saltwater habitats. The snails collected in seawater were smaller in size, and likely were juveniles that were migrating into streams from oceanic habitats.

Size distribution of $N$. auriculata is related to distance from the ocean, even at the small spatial scale of 66 $m$ examined in the Uufau river ; the farther upstream the site, the larger the size of the snails. This has been reported for neritids over large-scale distances (e.g. several $\mathrm{km}$ ) by Resh et al. (1990) and Schneider \& Lyons (1993).

$N$. auriculata's restriction to areas near the river mouth is likely related to its limited abilities to withstand dislodgment. In our hydraulic stress test, it showed the lowest dislodgment resistance of any neritid species tested. However, its salinity tolerance permits it to occur into the saltwater-freshwater transition zone.

The $>24$-hr survivorship of the normally seawaterinhabiting Nerita spp. in the freshwater rearings may provide insights into how the Neritidae evolved the ability to invade stream habitats. Some Nerita spp. occur submerged in the near-shore marine environment, but others occur in the splash zones on exposed rock. When there, they would be exposed to rainwater, and sometimes to large amounts ; these conditions could be considered analogous to those in a freshwater stream habitat. Perhaps this tolerance to freshwater exposure served as their entree to what would eventually become the neritid's successful occupancy of freshwater habitats.

\section{Acknowledgments}

Data collected in austral spring 1995 were part of the course «Biology and Geomorphology of Tropical Islands» taught at the University of California, Berkeley's Richard B. Gump South Pacific Biological Research Station in Moorea, French Polynesia. This paper is contribution no. 51 from the station. We thank Ferenc de Szalay, Pam Jutte, and Laurence E. Cheng for field assistance, and Alan Kohn and Janet Y. Uriu-Hare for their comments on this manuscript.

\section{References}

Bovbjerg R.V. 1984. - Habitat selection in two intertidal snails, genus Nerita. Bull. Mar. Sci., 34 : 185-196.

Dudgeon D. 1989. - Ecological strategies of Hong Kong Thiaridae (Gastropoda : Prosobranchia). Malacol. Rev., 22:39-53.

Ford J.I. \& Kinzie R.A. 1982. — Life crawls upstream. Nat. Hist., 91 : 62-66.

Govidan K. \& Natarajan R. 1972. - Studies on Neritidae (Neriticae : Prosobranchia) from peninsular India. Ind. Natl. Sci. Acad. Proc., Part B, 28 : 225-239.

Hazel W.N. \& Johnson M.S. 1990. - Microhabitat choice and polymorphism in the land snail Theba pisana (Müller). Heredity, 65 : 449-454.

Haynes A. 1984. - Guide to the brackish and freshwater gastropods of Fiji. Institute of Natural Resources, University of the South Pacific, Fiji : $39 \mathrm{p}$.

Haynes A. 1985. - The ecology and local distribution of non-marine aquatic gastropods in Viti Levu, Fiji. Veliger, $28: 204-210$.

Haynes A. 1988. - Notes on stream Neritids (Gastropoda : Prosobranchia) of Oceania. Micronesica, 21 : 93-102.

Layzer J.B. \& Madison L.M. 1995. - Microhabitat use by freshwater mussels and recommendations for determining their instream flow needs. Regul. Rivers : Res. Manage., $10: 329-345$.

Marquet G. 1987. - Périlogie des anguilles de Tahiti-Moorea en Polynésie Francaise. Diplôme de l'Ecole Pratique des Hautes Etudes, Paris : $150 \mathrm{p}$.

Marquet G. 1988. —-Les eaux intérieures de la Polynésie Francaise. Principales caractéristiques physiques, chimiques et biologiques. Thèse de Doctorat de l'Université Paris VI : 233 p.

Merritt R.W., Cummins K.W. \& Resh V.H. 1996. - Design of aquatic insect studies : collecting, sampling and rearing techniques. pp. 12-28. Kendall/Hunt Publishing Company. In R.W. Merritt and K.W. Cummins (Eds.) An Introduction to the Aquatic Insects of North America : $862 \mathrm{p}$.

Pointier J.P. \& Marquet G. 1990. - Taxonomy and distribution of freshwater mollusks of French Polynesia, Venus, $49: 215-231$.

Resh V.H., Barnes J.R. \& Craig D.A. 1990. — Distribution and ecology of benthic macroinvertebrates in the Opunohu river catchment, Moorea, French Polynesia. Annls. Limnol., 26 : 195-214. 
Resh V.H., Barnes J.R. Benis-Steger B. \& Craig D.A. 1992. — Life history features of some macroinvertebrates in a French Polynesia stream. Stud. Neotrop. Fauna Environ., 27 : 145-153.

Resh V.H. \& de Szalay F.A. 1995. - Streams and rivers of Oceania. pp. 717-736. In C.E. Cushing, K.W. Cummins \& G.W. Minshall (Eds.). River and Stream Ecosystems. Elsevier, New York : 817 p. Schneider D.W. \& Frost T.M. 1986. - Massive upstream migrations by a tropical freshwater neritid snail. Hydrobiologia, $137: 153$ 157.

Schneider D.W. \& Lyons J. 1983. - Dynamics of upstream migrations by a tropical freshwater neretid snail. Hydrobiologia, 12 : 3-16.
Statzner B., Gore J.A. \& Resh V.H. 1988. - Hydraulic stream ecology : observed patterns and potential application. J. N. Am. Benth. Soc., $7: 307-360$.

Vermeji G.J. 1971. - Substratum relationships of some tropical Pacific intertidal gastropods. Int. J. Life Oceans Coast. Waters, 10 : 315-320.

Winget R.N. 1985. - Methods for determining successful reclamation of stream ecosystems. pp. 165-192. In J.A. Gore Ed. The Restoration of Rivers and Streams. Butterworth Publishers, Stoneham, Massachusetts. 